\title{
Seasonal Progression and Agronomic Impact of Tobacco streak virus on Soybean in Wisconsin
}

P. F. Rabedeaux, Former Graduate Research Assistant, Department of Plant Pathology, University of WisconsinMadison, 1630 Linden Drive, Madison 53706; J. M. Gaska, Outreach Specialist, Departments of Agronomy and Plant Pathology, University of Wisconsin-Madison, 1575 Linden Drive, Madison 53706; and N. C. Kurtzweil, Research Specialist, and C. R. Grau, Professor, Department of Plant Pathology, University of Wisconsin-Madison, 1630 Linden Drive, Madison 53706

\begin{abstract}
Rabedeaux, P. F., Gaska, J. M., Kurtzweil, N. C., and Grau, C. R. 2005. Seasonal progression and agronomic impact of Tobacco streak virus on soybean in Wisconsin. Plant Dis. 89:391-396.

Pod necrosis and dieback of terminal portions of stems, commonly called bud blight, are observed in soybean fields and associated with Tobacco streak virus (TSV), an understudied virus of soybean. Furthermore, many TSV-infected plants are asymptomatic. The objectives of this study were to characterize the distribution and seasonal progress of TSV-infected plants in both natural and controlled epidemics, and the agronomic impact of TSV on soybean in plots with controlled introduction of inoculum. Incidence of TSV-positive samples ranged from 17 to 56\% in a general survey. In the presence of natural sources of inoculum, the incidence of TSVinfected plants ranged from 10 to $95 \%$ depending on cultivar and location, and peaked at growth stage R2, but detection dropped dramatically at R5. During 2001, significant yield loss and incidence of mottled seed were associated with TSV, but results were confounded by a high incidence of SMV. In 2002, SMV was controlled by cultivar selection, and a $25 \%$ reduction in grain yield was attributable to TSV. The incidence of mottled seed and green stem syndrome were low in the presence of TSV. Reductions in plant density and final plant height contributed to reduced yields. However, no significant differences were found in seed number per plant and 100-seed weight. Data indicate that plant mortality was the main mechanism by which TSV caused yield loss in induced epidemics.
\end{abstract}

The appearance of the soybean aphid (Aphis glycines Matsumura), a vector of Soybean mosaic virus (SMV), and the bean leaf beetle (Cerotoma trifurcata Forster), a vector of Bean pod mottle virus (BPMV), is concurrent with a rise in viruslike symptoms in soybean (Glycine max) in fields throughout the north central region of the United States $(1,3,5,9,15,21)$. Besides characteristic symptoms of mosaic, mottle, and rugosity, a high incidence of mottled seed coat (bleeding hilum), as well as green stem syndrome (GSS), also have increased in recent years $(5,9,11,16)$. Pod necrosis and dieback of terminal portions of stems, commonly called bud blight, has been observed in the past and in recent years $(6,11,14)$. Bud blight of soybean has several known causal agents, including Tobacco ringspot virus (TRSV), Tomato ringspot virus (TomRSV), and SMV (14). However, Tobacco streak virus (TSV) has emerged as another cause of bud blight in Brazil $(1,4)$ and the United

Corresponding author: C. R. Grau

E-mail: cg6@plantpath.wisc.edu

Accepted for publication 18 November 2004.

DOI: 10.1094/PD-89-0391

(C) 2005 The American Phytopathological Society
States (6). More recently, TSV was isolated from plants expressing symptoms of bud blight in commercial soybean fields in Wisconsin (11) and Oklahoma (23). There are no published data on the effect of TSV on agronomic variables such as yield loss, seed weight, and seed quality. TSV is regarded as an understudied virus of soybean and merits further investigation to ascertain its importance to soybean health and productivity in the north central region of the United States.

TSV has a host range of more than 140 genera, including members of the Solanaceae and Leguminosae $(2,6,7,13,17,18,20)$. TSV has been found several times in high incidence among weeds bordering agricultural fields, which could serve as a source of TSV inoculum $(2,7,18,20)$. Several species of thrips, including Microcephalothrips abdominalis (12) and Thrips tabaci (22), have been implicated in transmission of TSV. Johnson (18) was first to report the association of thrips and TSV by placing plants in cages with a fine mesh screen small enough to exclude such insects as alate aphids, but large enough to allow thrips to pass through to the plants. A mode of transmission described by Sdoodee and Teakle (22) is slightly different than a traditional intimate vector-virus relationship. They described a mechanism of transmission by which thrips passively obtain pollen from TSV-infected plants, and upon landing and feeding on a new host, mechanically inoculate that new host with the TSV-infected pollen through wounds on the plant. The virus and insect never come into direct contact in this mechanism; however, the transmission of TSV still is thought to be specific to thrips. Kaiser et al. (19) explored seed transmission of TSV in bean (Phaseolus vulgaris L.) and showed that seed transmission varied by TSV isolate. They also established that infection of embryos occurs upon transfer of infected pollen to a healthy ovule. Seed transmission rates in $P$. vulgaris cv. Black Turtle Soup were between 0.5 and $33 \%$ (19).

The source of primary inoculum of TSV and vector relationships have not been determined for soybean. Incidence of TSV in Brazilian soybean fields was lowered significantly by delaying planting date (1) and by application of the systemic insecticide aldicarb (4). It was speculated that delayed planting resulted in avoidance of thrips, and insecticides directly controlled thrips. However, definitive evidence was not presented to support the concept that thrips are the primary vector of TSV in soybean fields. Published reports on other hosts and insecticide trials provide circumstantial evidence that thrips are involved in some manner in the plant-to-plant movement of TSV in soybean fields $(1,4,19,20,22)$. It is not known whether the levels of TSV detected in commercial fields are the sole result of seed transmission (8) or whether there is plant-to-plant movement of TSV during a growing season.

The objectives of this study were to (i) assess the geographic distribution of TSV in Wisconsin, (ii) characterize seasonal progress of TSV-infected plants in both natural and controlled epidemics, and (iii) determine the agronomic impact of TSV on soybean in plots with controlled introduction of inoculum.

\section{MATERIALS AND METHODS \\ Enzyme-linked immunosorbent assay (ELISA) for TSV. Leaves were ground in a 1:10 (wt/vol) dilution of phosphate- buffered saline (PBS). Ground samples were then diluted 1:5 (vol/vol) into 96-well microtiter plates (Nalge Nunc Interna-}


tional, Rochester, NY) using PBS, $\mathrm{pH}=$ 7.2, for TSV. ELISA kits for TSV were obtained from Agdia (Elkhart, IN) for detection of virus in sampled leaves by following manufacturer's protocols. Absorbance at $405 \mathrm{~nm}\left(A_{405 \mathrm{~nm}}\right)$ was assessed using an EL 800 Universal Microplate Reader (Bio-Tek, Winooski, VT).

Distribution of TSV. Soybean plants were sampled in cultivar trials located in southern Wisconsin near Janesville, Racine, Lancaster, and Arlington, and central Wisconsin near Fond du Lac, Galesville, and Hancock. All trials were planted between 1 May and 25 May 1999, and the same source of seed was used for each cultivar at all locations. Seed lots were not assayed for incidence of seed transmission. Soybean cultivars were planted at a rate of 500,000 seeds per ha and at a depth of $2.5 \mathrm{~cm}$. Individual plots were $3.0 \times 7.6 \mathrm{~m}$, and rows were spaced 19 $\mathrm{cm}$ apart. Plots were managed at each location with standard agronomic practices for seedbed preparation and plant nutrition. Metachlor (Dual, 2.3 liters $\mathrm{ha}^{-1}$ ) and thifensulfuron methyl (Pinnacle, $18.3 \mathrm{ml}$ $\mathrm{ha}^{-1}$ ) were applied for weed suppression. The previous year's crop was corn at all locations. A randomized complete block design with three or four replications was used at each location. Natural inoculum was relied upon for introduction of TSV into the plot area. The cultivars BSR101, Hardin, and Sturdy were sampled once during growing season at growth stage R4. Five leaves were collected in a W-pattern from five different sites within each plot (replication) for a total of 25 leaves per cultivar. The five leaves were bulked to constitute one of five total samples within replications for each cultivar. Samples were immediately placed on ice for transport and stored at $-20^{\circ} \mathrm{C}$ until assayed for TSV.

Seasonal incidence of TSV in natural epidemics. The seasonal incidence of TSV-infected soybean plants was studied in experiments conducted at the Arlington Agricultural Research Station, Arlington, WI, and Rock County Farm near Janesville, WI, in 2001 and 2002. Natural inoculum was relied upon for introduction of TSV into the plot area. Plots were planted at Arlington on 10 May and 2 May, and 1 May and 6 May at the Rock County Farm in 2001 and 2002, respectively. Seeding rates were as above. Rows were spaced at $76 \mathrm{~cm}$ within individual plots of $3.0 \times 7.6$ m. Metachlor (Dual, 2.3 liters ha ${ }^{-1}$ ), thifensulfuron methyl (Pinnacle, $18.3 \mathrm{ml} \mathrm{ha}^{-1}$ ), and cloransulam methyl (First Rate, 21.9 $\mathrm{ml} \mathrm{ha}^{-1}$ ) were applied for weed suppression. The previous year's crop was soybean at Arlington and corn at Rock County. A randomized complete block design was used, and each soybean cultivar was replicated four times.

Plots were sampled three times to determine the incidence of plants infected by TSV. Plots were sampled by removing the youngest fully expanded trifoliate leaf from 20 randomly selected plants within each plot. At Arlington, samples were collected on 3 July, 8 August, and 24 August corresponding to growth stages V6, R2, and R5, respectively. At Rock County, samples were collected on 21 June, 24 July, and 21 August corresponding to growth stages V5, R2, and R5, respectively. Samples were immediately placed on ice for transport and stored at $-20^{\circ} \mathrm{C}$ for future use.

In 2001, plots in Arlington and Janesville were harvested on 9 October with an Almaco SP20 Plot Combine (Allen Machine Co., Nevada, IA) at both locations, and yields were adjusted to $13 \%$ moisture content. Seed coat mottling was assessed as a percentage of mottled seeds per 100 arbitrarily sampled seeds per plot. Final plant height was calculated from a threeplant subsample per plot.

Agronomic impact of TSV in controlled epidemics. Field experiments were conducted at the West Madison Agricultural Research Station (ARS) in 2001 and 2002 to estimate yield loss associated with TSV. Plots were planted between 3 May and 10 May in both years at the rate described above. Rows were spaced at $76.2 \mathrm{~cm}$ apart in individual plots of $2.1 \times 3.0 \mathrm{~m}$. Metribuzin (Sencor, $1.8 \mathrm{~kg} \mathrm{ha}^{-1}$ ) and pendimethalin (Prowl, 0.6 liters ha ${ }^{-1}$ ) were applied for weed control. The field was irrigated three times during the growing season, and the previous year's crop was soybean. The soybean cultivar Hughes 261 RR (Woodstock, IL) was planted in 2001, and the public cultivar Colfax was planted in 2002. Colfax was chosen because it proved to be susceptible to TSV after mechanical inoculation in greenhouse trials and was resistant to SMV. SMV was common in the research plots and a possible confounding factor for the assessment of yield loss. The resistance to SMV in Colfax has not been attributed to a specific gene (10).

In 2001, treatments were arranged in a randomized complete block design with four replications. Treatments consisted of PBS and TSV. In 2002, a paired-plot design with three pairs was used, with each treatment being the percentage of total plants inoculated within the plot. The control pair was 0 and $0 \%$ plants inoculated, and the two TSV treatment pairs were 0 and $50 \%$ plants inoculated and 0 and $100 \%$ plants inoculated. The pairs were randomized within a block, and blocks were replicated three times.

Mechanical transmission was used to introduce TSV isolate "C" into the research plots for both years. TSV isolate $\mathrm{C}$ was isolated from plants collected from a private soybean field in south central Wisconsin in 2000 and was mechanically transmissible. TSV-C was passed through single local lesions on cowpea, and its identity was confirmed by bioassay on cowpea plants, ELISA, and electron microscopy of purified virions. Infectious sap was prepared by grinding the youngest trifoliolate leaf of infected Colfax plants in PBS, $\mathrm{pH}=$ 7.2 (Sigma Aldrich, St. Louis, MO) at an approximate 1:10 (wt/vol) dilution. Infectious sap was kept on ice throughout transport and inoculation. Plants were inoculated on 14 June (growth stage V3) in both years. Carborundum was dusted onto the youngest trifoliolate leaves, and two of three leaflets were lightly rubbed with a cotton swab dipped in infectious sap. Every plant was inoculated in the $100 \%$ treatment, and every other plant was inoculated in the $50 \%$ treatment.

Lambda-cyhalothrin (Warrior 1EC, $233.8 \mathrm{ml} \mathrm{ha}^{-1}$ ) was applied on 31 May 2002 to suppress bean leaf beetle populations and, in turn, to suppress both bean leaf beetle feeding damage and transmission of BPMV (9). The field was irrigated on 28 June $(1.25 \mathrm{~cm})$ and 5 July $(2.5 \mathrm{~cm})$ in 2002, and total precipitation from 24 May through 8 October was $38 \mathrm{~cm}$.

Samples were obtained by removing the center leaflet of the youngest, fully expanded trifoliolate leaf of 20 randomly selected plants per plot. Plots were sampled once at growth stage R5 in 2001. In 2002, plots were sampled six times: 5 June and 3 July, 19 July, 8 August, 26 August, and 4 September. The 5 June samples were collected prior to TSV inoculation and served to estimate the incidence of seed transmission of TSV. Samples were immediately placed on ice for transport and stored at $-20^{\circ} \mathrm{C}$ until assayed for TSV.

The incidence of GSS was assessed by two methods: visually as a percentage of plants expressing GSS symptoms per plot, and quantitatively as the number of plants per 2-m sample expressing GSS symptoms. Plots were harvested on 5 November 2001 and 11 October 2002. The incidences of mottled seed coat and purple seed stain, characteristics of seeds infected with $\mathrm{Cer}$ cospora spp., were assessed for 100 randomly selected seeds per plot. Seed weight was calculated as the total weight of 100 randomly selected seeds per plot. Final plant height was calculated as described above.

Greenhouse experiment. A greenhouse experiment was performed during the spring and summer of 2003 to supplement field data collected in 2001 and 2002. The goal of the experiment was to explore the agronomic and developmental effects of TSV on two soybean cultivars when inoculated at different growth stages. The soybean cultivars Colfax, susceptible to TSV and resistant to SMV, and Northrup King S19-90, susceptible to TSV and susceptible to SMV, were inoculated at growth stages VC, V3, and V5 with TSV-C. The youngest trifoliolate of each plant was inoculated, and control plants were mock inoculated with PBS buffer. A randomized complete block design with six replications was used; inoculation growth stage 
was the main plot and soybean cultivar was the subplot.

Growth stage was monitored throughout development of the plants. Final height and final growth stage were recorded, and pods and seeds were also harvested at that time. Number of pods per plant and number of seeds per plant were recorded 118 days the youngest trifoliolate leaf of each plant was sampled at 30, 37, 44, and 118 DPI, and ELISA was used to assay leaflets for TSV.

Statistical analysis. Means, standard errors, and least significant difference (LSD) values for field experiments in 2001 were calculated using PROC GLM in SAS for Windows, v.8 (SAS Institute, Cary, NC). Means, standard errors, and pair-wise difference $t$ tests for the greenhouse experiments and 2002 field experiment were calculated using PROC MIXED in SAS for Windows, v.8. Means of treatments for variables were compared using Fisher's postinoculation (DPI). The center leaflet of

protected least significant difference test at $P=0.05$ for greenhouse studies and $P=$ 0.10 for field studies. More rigorous $P$ values were used for greenhouse experiments because of our ability to control environmental conditions during the duration of the experiment. Pearson correlations were calculated using MINTAB for Windows v.12.1 (MINITAB Inc., State College, PA).

\section{RESULTS}

Statewide survey. TSV was detected in soybean at five of seven locations sampled in 1999 (Table 1). Incidence of TSVinfected plants ranged from 17 to $56 \%$; TSV was detected in all soybean cultivars evaluated and was found in major soybean growing regions of Wisconsin. Results of the survey in 1999 provided an incentive to continue an investigation of TSV as a pathogen of soybean in Wisconsin.

Seasonal TSV incidence in natural epidemics. TSV was identified in plots at

Table 1. Distribution of Tobacco streak virus (TSV) in Wisconsin in 1999

\begin{tabular}{llcc}
\hline Region & Location & Samples $^{\mathbf{z}}$ & TSV $^{\text {positive (\%) }}$ \\
\hline Southern & Janesville & 12 & 0 \\
& Racine & 9 & 33 \\
& Lancaster & 9 & 56 \\
\multirow{3}{*}{ Central } & Arlington & 12 & 17 \\
& Galesville & 12 & 0 \\
& Fond du Lac & 12 & 25 \\
& Hancock & 12 & 25 \\
\hline
\end{tabular}

${ }^{\mathrm{z}}$ Soybean cultivars BSR 101, Hardin, and Sturdy were sampled at each location. Four replications per cultivar were deployed at Janesville, Arlington, Fond du Lac, and Hancock, and three per cultivar at Racine and Lancaster.

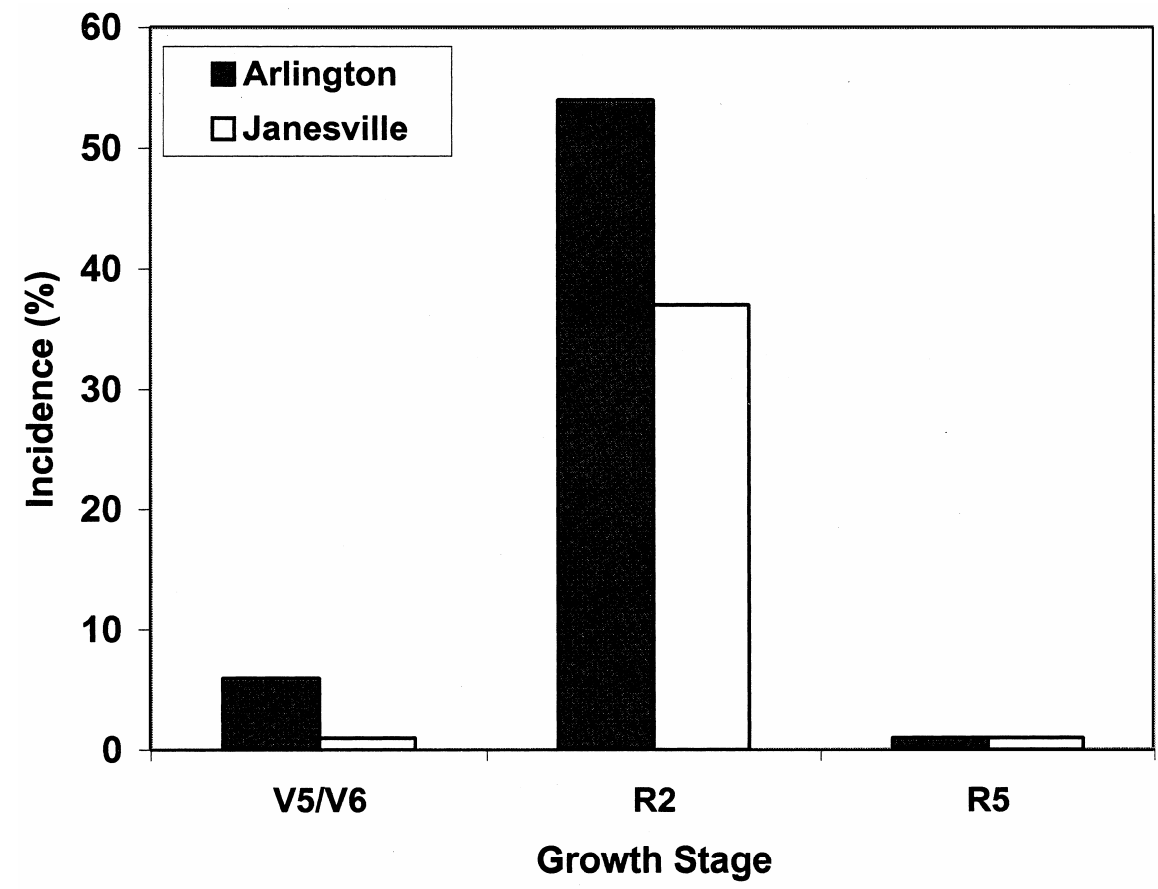

Fig. 1. Incidence of Tobacco streak virus (TSV) in a natural epidemic over the course of the 2001 growing season as monitored in research plots located at Arlington Agricultural Research Station, Arlington, WI, and Rock County Farm, Janesville, WI. Leaves were collected from 20 plants per replicate plot and were assayed by enzyme-linked immunosorbent assay to estimate incidence of TSVinfected plants at growth stages V5, V6, R2, and R5. TSV was not detected in 2002.
Arlington and Rock County in 2001 (Fig. 1), but not in 2002 (data not presented). Incidence of TSV-infected plants for all cultivars peaked at growth stage R2, but detection dropped dramatically at R5 at both locations in 2001 (Fig. 1). The mean incidence of TSV at Arlington increased from $6 \%$ on 3 July to $54 \%$ on 8 August followed by a decrease to $1 \%$ incidence on 24 August, the final sampling date (Fig. 1). Mean incidence of TSV at Janesville increased from $1 \%$ on 21 June to $37 \%$ on 24 July. A decrease to $1 \%$ was observed on 21 August, the final sampling date (Fig. 1).

The incidence of TSV-infected plants ranged from 10 to $95 \%$ at Arlington and 15 to $60 \%$ at Janesville (Table 2). The incidence of TSV-infected plants was higher at Arlington than at Janesville. Differences in incidence of TSV-infected plants were detected among the 36 cultivars evaluated at Arlington $(P=0.001)$, but not at Janesville. Overall, the relative reactions of cultivars to TSV were moderately similar at both locations (Pearson's rank correlation; $P=0.06, r=0.31)$.

Table 2. Incidence of plants infected by Tobacco streak virus (TSV) at growth stage R2 based on 80 plants assayed for each soybean cultivar grown at two locations in Wisconsin in 2001

\begin{tabular}{|c|c|c|}
\hline $\begin{array}{l}\text { Soybean } \\
\text { cultivar }\end{array}$ & $\begin{array}{l}\text { Arlington } \\
\text { TSV (\%) }\end{array}$ & $\begin{array}{c}\text { Janesville } \\
\text { TSV (\%) }\end{array}$ \\
\hline 392 Brand & 40 & 45 \\
\hline $92 \mathrm{~B} 37$ & 15 & 20 \\
\hline $92 \mathrm{~B} 62$ & 50 & 35 \\
\hline AG 2001 & 30 & 15 \\
\hline AG 2101 & 80 & 35 \\
\hline AG 2301 & 85 & 40 \\
\hline AP 2502 & 30 & 30 \\
\hline Bell & 80 & 40 \\
\hline BSR 101 & 75 & 40 \\
\hline Conrad 94 & 85 & 35 \\
\hline Corsoy 79 & 50 & 15 \\
\hline DKB 23-51 & 50 & 50 \\
\hline DSR 218 & 55 & 10 \\
\hline DSR 277 & 80 & 45 \\
\hline Dwight & 80 & 55 \\
\hline $\mathrm{H} 2000 \mathrm{RR}$ & 65 & 55 \\
\hline H2492 & 30 & 45 \\
\hline HS2106 & 55 & 40 \\
\hline Hughes 225 & 30 & 25 \\
\hline Hughes 261 & 55 & 45 \\
\hline LN 92-12033 & 70 & 50 \\
\hline Loda & 85 & 35 \\
\hline MRK 9824 RR & 60 & 30 \\
\hline Mycogen 5261 & 60 & 35 \\
\hline Newton & 35 & 60 \\
\hline RS 2498 & 55 & 35 \\
\hline RT 2441 & 65 & 35 \\
\hline S20-F8 & 45 & 25 \\
\hline S24-K4 & 10 & 25 \\
\hline Stine $2500-7$ & 25 & 35 \\
\hline Spansoy 201 & 40 & 35 \\
\hline Spansoy 250 & 40 & 50 \\
\hline Sturdy & 35 & 30 \\
\hline Titan & 50 & 20 \\
\hline Vinton 81 & 50 & 60 \\
\hline Williams 82 & 95 & 45 \\
\hline Trial mean & 54 & 37 \\
\hline Probability (\%) & 0.001 & NS \\
\hline LSD (10\%) & 22 & NS \\
\hline
\end{tabular}


Mosaic and mottle symptoms were observed at both locations in both years, but not symptoms of terminal necrosis. BPMV and SMV were identified by ELISA at both locations in 2001 and 2002 (data not presented). A high incidence of TSVinfected plants was observed, but in the absence of symptoms typically associated with plants infected by TSV. A high incidence of thrips was observed at both locations in 2001, but this putative vector of TSV was uncommon in 2002.

Agronomic impact of TSV in controlled epidemics. TSV was successfully introduced to experimental plots in both years. The incidence of TSV-infected plants peaked at 50\% in 2001 and 33\% in 2002 (Table 3). In 2002, first incidence of TSV was detected by the R1 growth stage on 3 July and increased to $13 \%$ in the halfinoculated treatment and $33 \%$ in the fully inoculated treatment when plants reached the R2 growth stage on 19 July (Fig. 2). As in 2001, the incidence of TSV-infected plants decreased as plants progressed into pod development stages starting at growth stage $\mathrm{R} 4$ in 2002. A small spike in TSV was detected on 26 August. An incidence of $40 \%$ TSVinfected plants was detected in control plots in 2001. In contrast, incidence of TSV was minimal in control plots in 2002.
Grain yield was less in the fully inoculated plots in both years (Table 3). In 2001, a significant $(P<0.03)$ yield loss from $2,493 \mathrm{~kg} \mathrm{ha}^{-1}$ to $1,921 \mathrm{~kg} \mathrm{ha}^{-1}$ was observed in plots with TSV-inoculated plants at West Madison (Table 3). In 2002, yield of variety Colfax was significantly $(P<$ 0.08 ) reduced from $3,396 \mathrm{~kg} \mathrm{ha}^{-1}$ in the noninoculated plots to $2,956 \mathrm{~kg} \mathrm{ha}^{-1}$ in the fully inoculated plots. Yield was not significantly reduced $(P<0.74)$ in the halfinoculated plots. Analysis of yield components showed that final plant density was significantly reduced $(P<0.09)$ from 15.1 plants per $\mathrm{m}$ (control) to 10.8 plants per $\mathrm{m}$ in plots that received TSV inoculum in 2002. Final plant height was significantly reduced $(P<0.02)$ during 2002 in the fully inoculated treatment. The half-inoculated treatment did not significantly affect final plant height $(P<0.94)$. This was consistent with the stunting symptoms typically observed for plants infected by TSV. Seed weight $(P<0.91, P<0.36)$, seed moisture $(P<0.27, P<0.70)$, pod number per plant $(P<0.74, P<0.16)$, and seed number per plant $(P<0.23, P<0.18)$ were not significantly affected by TSV treatments. In 2001, seed coat mottling was observed at a mean of $6 \%$ across all treatments. In 2002, however, the incidence of seed coat mot-

Table 3. Incidence of Tobacco streak virus (TSV)-infected plants and yield of soybean inoculated or noninoculated in field experiments in Wisconsin in 2001 and 2002

\begin{tabular}{lccccc}
\hline & \multicolumn{2}{c}{$\mathbf{2 0 0 1}$} & & \multicolumn{2}{c}{$\mathbf{2 0 0 2}$} \\
\cline { 2 - 3 } \cline { 5 - 6 } Treatment & Yield (bu/acre) & TSV incidence (\%) & & Yield (bu/acre) & TSV incidence (\%) \\
\hline Control & 37.1 & 40.0 & & 54.1 & 0.0 \\
$50 \%$ & ND & ND & & 53.4 & 13.0 \\
$100 \%$ & 28.6 & 50.0 & & 44.0 & 33.0 \\
$P$ value & 0.03 & NS & & 0.08 & 0.001 \\
LSD $(10 \%)$ & 7.7 & NS & & 8.2 & 3.4 \\
\hline
\end{tabular}

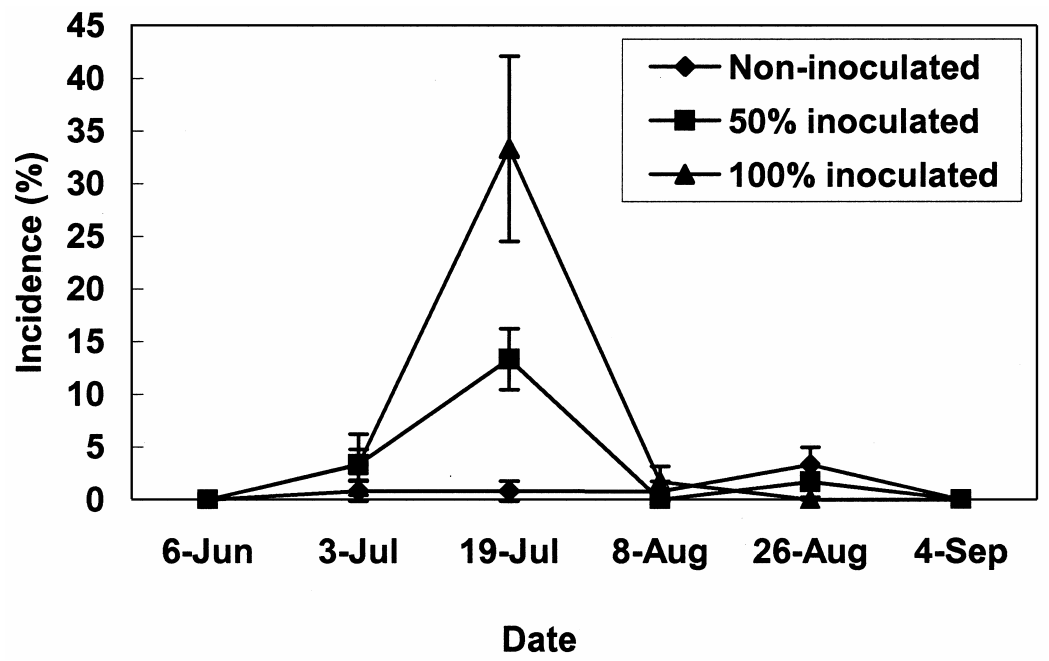

Fig. 2. Incidence of Tobacco streak virus isolate C (TSV-C) in an induced epidemic in 2002 over the course of the growing season as monitored in research plots. Control denotes noninoculated plots; $50 \%$ denotes plots in which half the plants were mechanically inoculated with TSV-C; $100 \%$ denotes plots in which all plants were mechanically inoculated with TSV-C. Plants were mechanically inoculated with TSV-C on 6 June. Leaflets were collected from 20 plants per replicate plot on 6 June, 3 July, 19 July, 8 August, 26 August, and 4 September, and enzyme-linked immunosorbent assay was used to determine the incidence of plants infected by TSV-C. tling was less than $1 \%$ and not affected by TSV compared with seeds harvested from noninoculated control plots $(P<0.47)$. Purple seed stain was not significantly affected by TSV in $2001(P<0.66)$ or $2002(P<1.00)$ regardless of incidence of infected plants. Incidence of GSS was not significantly affected by either the fully inoculated treatment $(P<0.53)$ or the halfinoculated treatment $(P<0.97)$. Treatment with lambda-cyhalothrin (Warrior) was used to control bean leaf beetle populations and contributed to suppressing BPMV to a $10 \%$ incidence.

Greenhouse study. Significant reductions in final height were observed for plants inoculated at all growth stages compared with the noninoculated controls $(P<$ $0.0001)$. Reductions in final height ranged from 60 to $82 \%$ of the noninoculated controls, and reductions were less as inoculation was delayed to later growth stages (Fig. 3).

Pod number per plant $(P<0.0001)$, seed number per plant $(P<0.0001)$, and seed weight per plant $(P<0.0001)$ were all significantly reduced from the noninoculated control for both soybean cultivars evaluated (Table 4). Seed number per plant was significantly higher for Northrup King S19-90, as plants inoculated at VC and V5 produced 37 and 66 seeds per plant, respectively, while none of the infected Colfax plants produced seed. Pods produced by Colfax plants did not develop seeds. Pod number per plant $(P<0.14)$ and seed weight per plant $(P<0.07)$ were not significantly different for Northrup King S1990 across all inoculation times.

TSV was detected by ELISA in all inoculated plants except for plants that died during the experiment and two Northrup King S19-90 plants that did not become systemically infected. ELISA values at 405 $\mathrm{nm}$ were not significantly affected by soybean line at 30 DPI $(P<0.80), 37$ DPI $(P$ $<0.67)$, and 44 DPI $(P<0.14)$, and values ranged from 0.498 to 1.115 . At 118 DPI, the $A_{405 \mathrm{~nm}}$ of 0.429 observed for Northrup King S19-90 inoculated at V5 was significantly lower than the $A_{405 \mathrm{~nm}}$ observed for all three Colfax inoculated at all growth stages $(P<0.004)$.

\section{DISCUSSION}

TSV was found to naturally occur in cultivar trials in the major soybean production regions of Wisconsin. This study represents the first attempt to monitor the incidence and seasonal progress of TSVinfected soybean plants in a natural epidemic. The incidence of TSV-infected plants peaked at growth stage R2, but declined when plots were sampled again at growth stage R5 in 2001. These results occurred in natural epidemics at both locations in 2001, and in a controlled epidemic in 2002. The decline in incidence of TSVinfection was not expected, and current published data do not provide a plausible 
explanation. The seasonal progress of TSV observed in the current study was in direct contrast to SMV. Steinlage et al. (24) reported that the incidence of SMV-infected plants increased during the growing season and peaked at later growth stages. We propose that the late season decline of TSVinfected plants is an intrinsic feature of TSV rather than the result of interactions with the other viruses or errors in sampling and/or ELISA analysis. Greenhouse studies were conducted to gain insight into the behavior of TSV in the field. Data on plant height and ELISA data from the greenhouse experiment strongly suggest that a sampling bias may have existed because of differing heights of infected and noninfected plants in the field study. TSV-C reduced plant height $60 \%$ when plants were infected as late as growth stage V5 in the greenhouse study. In field studies, stunted plants within the canopy may have been missed during the collection of the youngest fully expanded trifoliolate leaf at the top of the crop canopy. In the greenhouse, we were able to detect TSV in infected plants through the flowering growth stage. Also, we observed that soybeans infected with TSV were frequently killed. Thus, not only were stunted plants enclosed by a healthy canopy and not sampled, but also infected plants were killed and not available for assay at later growth stages. The disappearance of infected plants from the system may have resulted in a drop in incidence. These results indicate that the timing and methods used to collect samples for TSV incidence determinations can be very important.

The source(s) of primary inoculum is unknown for the natural epidemics of TSV at the seven field locations in 1999 and Arlington and Janesville in 2001. The same source of seed was used at each location in 1999, a year when TSV was detected at five of the seven locations. Although TSV is reported to be seed transmitted (8), our data suggest that seedborne inoculum and seed transmission did not contribute to the epidemics monitored in Wisconsin. We speculate that TSV inoculum originated from infected plants outside the soybean field and a suitable vector was active at the TSV-positive locations. Each site had numerous weed species in the vicinity, and white sweetclover and white clover are common in uncultivated areas surrounding fields $(7,18,20)$. Alfalfa was common at both locations, but the role of this forage legume as a source of TSV inoculum is not clear. Hampton et al. (13) reported alfalfa as a nonhost for TSV, but we have serologically detected TSV in alfalfa and have mechanically transmitted TSV from alfalfa to alfalfa (data not shown).

A high incidence of thrips was observed at both locations in 2001, but this putative vector of TSV was uncommon in 2002. Data and observations from our studies neither refute nor strengthen evidence that thrips are a vector of TSV $(1,4,12,19,20,22)$. In a year of high thrips activity, 2001, a high incidence of TSVinfected plants was observed in plots with natural epidemics. In contrast, in 2002, a year of minimal thrips activity, TSVinfected plants were not detected at any location. Furthermore, in controlled inoculum experiments, a high incidence of TSV was observed in control plots in 2001, but the incidence of TSV was minimal in control plots in 2002. The lack of TSV in 2002 suggests that either thrips $(3,11,17,18)$ were missing from the system, or that thrips were present, but lacked access to local sources of TSV. The direct role for thrips in transmission of TSV from either forages to soybean or from soybean to soybean has not been shown. However, forage legume species were common at all locations.

A high incidence of TSV in control plots and the presence of SMV in all plots in the 2001 experiment precluded drawing conclusions about the relationships between incidence of TSV and agronomic variables, such as yield and seed quality. Thus, in 2002, an SMV-resistant and TSVsusceptible variety, Colfax, was used to alleviate disease pressure from SMV. The incidences of not only SMV, but also AMV and BPMV, were low in 2002. In 2002, yield was significantly reduced in plots in which TSV incidence reached 33\%; yield was not significantly reduced in plots in which TSV incidence was $13 \%$. The yield data suggest that soybean has the ability to compensate for yield loss during minor outbreaks of TSV. Final plant population density was reduced $28 \%$ in the fully inoculated treatment and $14 \%$ in the halfinoculated treatment. In comparison, yield was reduced $25 \%$ in the fully inoculated treatment, but not in the half-inoculated treatment. Combined, the final plant density data and yield data strongly suggest that yield loss is attributable to loss of infected plants from the system. Indirect evidence that supports our theory comes from our seed quality data. No significant effects were observed on seed quality. Although TSV may not actually affect seed quality, it is more likely that we did not observe differences in seed quality because the infected plants did not contribute any seeds to our analyses.

Application of pesticides targeted at thrips (3) and delaying of planting time to avoid thrips (1) have both been shown to be effective in reducing TSV incidence in Brazilian soybean systems. The Brazilian data provide indirect evidence that thrips are an important vector of TSV and therefore a

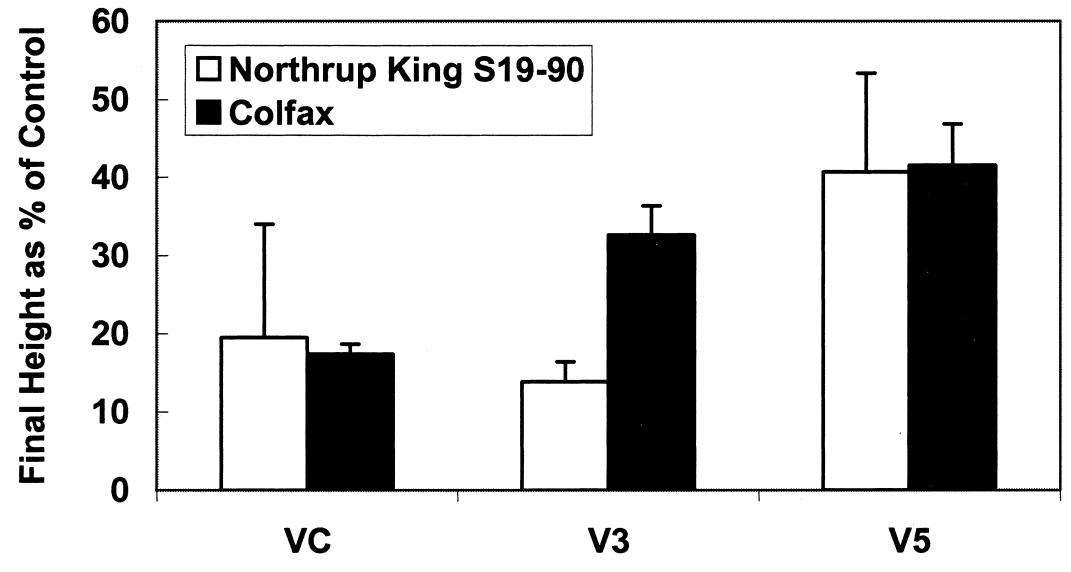

Growth Stage Inoculated

Fig. 3. Comparison of final heights of soybean lines Colfax and Northrup King S19-90 inoculated with Tobacco streak virus isolate C (TSV-C) compared with a noninoculated control under greenhouse conditions. Final heights were taken 118 days postinoculation. The youngest trifoliolate leaves were inoculated with TSV-C at VC, V3, or V5. Bars represent standard error of the mean. Mean final height and standard error of mock-inoculated Northrup King S19-90 plants were $112.3 \mathrm{~cm}$ and 23.8, respectively. Mean final height and standard error of mock-inoculated Colfax plants were $85.3 \mathrm{~cm}$ and 13.4 , respectively.

Table 4. Comparison of agronomic variables of soybean cultivars Colfax and Northrup King S19-90 inoculated with Tobacco streak virus isolate $\mathrm{C}$ at different growth stages under greenhouse conditions ${ }^{\mathrm{Z}}$

\begin{tabular}{lrrrrrrrr}
\hline \multirow{2}{*}{$\begin{array}{l}\text { Growth stage } \\
\text { inoculated }\end{array}$} & \multicolumn{2}{c}{ Pod number per plant } & & \multicolumn{2}{c}{ Seed number per plant } & & \multicolumn{2}{c}{ Seed weight per plant $(\mathrm{g})$} \\
\cline { 2 - 3 } & Colfax & NKS19-90 & & Colfax & NKS19-90 & & Colfax & NKS19-90 \\
\hline Noninoculated & $120.3 \mathrm{a}$ & $123.7 \mathrm{a}$ & & $225.2 \mathrm{a}$ & $239.2 \mathrm{a}$ & & $54.2 \mathrm{a}$ & $53.7 \mathrm{a}$ \\
VC & $0.2 \mathrm{~b}$ & $18.3 \mathrm{~b}$ & & $0.0 \mathrm{~b}$ & $37.2 \mathrm{bc}$ & & $0.0 \mathrm{~b}$ & $15.3 \mathrm{~b}$ \\
V3 & $6.8 \mathrm{~b}$ & $0.5 \mathrm{~b}$ & & $0.0 \mathrm{~b}$ & $0.0 \mathrm{c}$ & & $0.0 \mathrm{~b}$ & $0.0 \mathrm{c}$ \\
V5 & $3.8 \mathrm{~b}$ & $28.8 \mathrm{~b}$ & & $0.0 \mathrm{~b}$ & $65.7 \mathrm{~b}$ & & $0.0 \mathrm{~b}$ & $10.1 \mathrm{bc}$ \\
\hline
\end{tabular}

${ }^{\mathrm{z}}$ Means followed by different letters are statistically significant at $P=0.05$. 
target for control strategies. Such strategies would need to be evaluated for effectiveness in the north central United States.

TSV was detected in all soybean cultivars used in the study. However, some cultivars had lower incidences of TSVinfected plants at one of two locations in 2001. The cultivars Colfax and Northrup King S19-90 were both symptomatic in greenhouse experiments, but Northrup King S19-90 produced more pods and seeds than Colfax. These data provide evidence that soybean cultivars are not equally susceptible to TSV.

The agronomic importance of TSV on a commercial scale is not known. However, TSV has a wide distribution in Wisconsin and caused yield loss in induced epidemics in field studies. These findings provide evidence that TSV is contributing in part to losses of soybean productivity caused by the insect-virus complex in the north central United States.

\section{ACKNOWLEDGMENTS}

We thank David Doughty, Mary Lee-Burrows, and A. M. Mondjana of the University of Wisconsin-Madison for their technical assistance with ELISA.

\section{LITERATURE CITED}

1. Almeida, A. M. R., and Corso, I. C. 1991. Effect of sowing time on the incidence of bud blight in soybean (Glycine $\max$ L. Merr.). J. Phytopathol. 132:251-257.

2. Berkeley, G. H., and Phillips, J. H. H. 1943. Tobacco Streak. Can. J. Res. 21:181-190.

3. Clark, A. J., and Perry, K. L. 2002. Transmissibility of field isolates of soybean viruses by Aphis glycines. Plant Dis. 86:1219-1222.
4. Costa, A. S., and Costa, C. L. 1980. Brazilian soybean bud blight caused by Brazilian tobacco streak virus reduced by the application of systemic insecticides aldicarb, disulfoton, phorate, Caliothrips phaseoli as vectors. Fitopatol. Bras. 5:115-120.

5. Doughty, D. M., Lee, M. E., Kurtzweil, N. C., Boerboom, C. M., and Grau, C. R. 2001. Occurrence of soybean viruses and association with green stem of soybean in Wisconsin. (Abstr.) Phytopathology 91:S176-177.

6. Fagbenle, H. H., and Ford, R. E. 1970. Tobacco streak virus isolated from soybeans, Glycine max. Phytopathology 60:814-820.

7. Fulton, R. W. 1948. Hosts of the tobacco streak virus. Phytopathology 38:421-428.

8. Ghanekar, A. M., and Schwenk, F. W. 1974. Seed transmission and distribution of tobacco streak virus in six cultivars of soybeans. Phytopathology 64:112-114.

9. Giesler, L. J., Ghabrial, S. A., Hunt, T. E., and Hill, J. H. 2002. Bean pod mottle virus: A threat to U.S. soybean production. Plant Dis. 86:1280-1289.

10. Graef, G. L., Specht, J. E., Korte, L. L., and White, D. M. 1994. Registration of Colfax soybean. Crop Sci. 34:818.

11. Grau, C. R., Wedberg, J. L., Hogg, D. B., Kurtzweil, N. C., Myers, S. W., and Gaska, J. M. 2001. Control strategies for soybean aphid-virus complex. Proc. Soybean Seed Res. Conf. 31st.

12. Greber, R. S., Klose, M. J., and Teakle, D. S. 1991. High incidence of tobacco streak virus in tobacco and its transmission by Microcephalothrips abdominalis and pollen from Ageratum houstonianum. Plant Dis. 75:450452.

13. Hampton, R., Beczner, L., Hagedorn, D., Bos, L., Inouye, T., Barnett, O., Musil, M., and Meiners, J. 1978. Host reactions of mechanically transmissible legume viruses of the northern temperate zone. Phytopatholology 68:989-997.

14. Hartman, G. L., Sinclair, J. B., and Rupe, J. C., eds. 1999. Compendium of Soybean Diseases. 4th ed. American Phytopathological Society, St. Paul, MN

15. Hill, J. H., Alleman, R., Hogg, D. B., and Grau, C. R. 2001. First report of transmission of Soybean mosaic virus and Alfalfa mosaic virus by Aphis glycines in the New World. Plant Dis. 85:561.

16. Hobbs, H. A., Hartman, G. L., Wang, Y., Hill, C. B., Bernard, R. L., Pedersen, W. L., and Domier, L. L. 2003. Occurrence of seed coat mottling in soybean plants inoculated with Bean pod mottle virus and Soybean mosaic virus. Plant Dis. 87:1333-1336.

17. Hull, R. 2002. Matthews' Plant Virology. 4th ed. Academic Press, San Diego.

18. Johnson, J. 1936. Tobacco streak, a virus disease. Phytopathology 26:285-292.

19. Kaiser, W. J., Wyatt, S. D., and Klein, R. E. 1991. Epidemiology and seed transmission of two tobacco streak virus pathotypes associated with seed increases of legume germ plasm in eastern Washington. Plant Dis. 75:258-264

20. Kaiser, W. J., Wyatt, S. D., and Klein, R. E. 1982. Natural hosts and vectors of tobacco streak virus in eastern Washington wild plant species. Phytopathology 72:1508-1512.

21. Mabry, T. R., Hobbs, H. A., Steinlage, T. A., Johnson, B. B., Pedersen, W. A., Spencer, J. L. Levine, E., Isard, S. A., Domier, L. L., and Hartman, G. L. 2003. Distribution of leaffeeding beetles and Bean pod mottle virus (BPMV) in Illinois and transmission of BPMV in soybean. Plant Dis. 87:1221-1225.

22. Sdoodee, R., and Teakle, D. S. 1987. Transmission of tobacco streak virus by Thrips tabaci: A new method of plant virus transmission. Plant Pathol. 36:377-380.

23. Sherwood, J. L., and Jackson, K. E. 1985 Tobacco streak virus in soybean. Oklahoma. Plant Dis. 69:727.

24. Steinlage, T. A., Hill, J. H., and Nutter, F. W., Jr. 2002. Temporal and spatial spread of Soybean mosaic virus (SMV) in soybeans transformed with the coat protein gene of SMV. Phytopathology 92:478-486. 